\title{
IYÁ MI OXORONGÁ: OLHARES SAGRADOS DO FEMININO NO CANDOMBLÉ
}

\section{IYÁ MI OXORONGÁ: SACRED LOOKS OF THE FEMALE IN CANDOMBLE}

\author{
${ }^{1}$ Ana Angélica Monteiro de BARROS*; ${ }^{2}$ Vitor Amorim Moreira de AZEVEDO \\ ${ }^{1}$ Universidade do Estado do Rio de Janeiro, Faculdade de Formação de Professores, Departamento de Ciências, São \\ Gonçalo, Rio de Janeiro, Brasil, ${ }^{2}$ Universidade do Estado do Rio de Janeiro, Faculdade de Formação de Professores, \\ Programa de Pós-Graduação em Ensino de Ciências, Ambiente e Sociedade, São Gonçalo, Rio de Janeiro, Brasil. \\ *anaangbarros@gmail.com
}

Submitted: 24/11/2020; Accepted: 01/03/2021; Published: 21/03/2021

\section{RESUMO}

A figura feminina detém uma força misteriosa que provoca, até os dias de hoje, fascínio e medo, características que estão intrinsecamente associadas às Iyá Mi Oxorongá, que são divindades que chegaram ao Brasil por meio da diáspora espiritual africana. Neste trabalho, pretende-se estabelecer a relação do culto das Iyá Mi com o matriarcado e o poder feminino no candomblé, buscando compreender o papel social e sagrado das sacerdotisas nos espaços religiosos, além de ratificar o protagonismo feminino nessa religião afro-brasileira. A abordagem qualitativa foi adotada para se discutir os mitos cosmogônicos de criação do mundo e da humanidade através das divindades Odudua e Obatalá. O referencial teórico se baseou na literatura especializada de livros e artigos buscados nas bases Google Scholar e SciElo. Essa análise foi complementada com a interpretação do mito que consta no primeiro verso do itan 204 do livro a "A Mitologia dos Orixás" de Reginaldo Prandi, que apresenta o arquétipo feminino das Iyá Mi Oxorongá, as Feiticeiras Ancestrais associadas à Odudua, a grande Mãe da Criação, e ao poder matriarcal das sacerdotisas do candomblé. Uma das versões do mito cosmogônico apresenta Odudua como a responsável por gestar o mundo usando a Igbá-Odu, a cabaça da existência, e a Obatalá de fazer surgir a humanidade. O culto a essas divindades é praticado no candomblé, onde Odudua está relacionada à ancestralidade feminina e a sua capacidade em gerenciar a vida e a morte. A análise desse mito permitiu mostrar essa simbologia vivenciada pelas Iyalorixás, mulheres que se destacam por assumir sua fé para manter unidos os elos das comunidades religiosas, que são espaços de resistência diante de uma sociedade culturalmente ocidentalizada e patriarcal. O mito das Iyá Mi está intimamente conectado a essa questão, ressaltando o olhar sagrado do poder feminino relacionado à condição de ser mulher.

PALAVRAS-CHAVE: Feiticeiras, Matrifocalidade, Mitos, Poder Feminino, Religiões AfroBrasileiras.

\begin{abstract}
The female figure has a mysterious force that, until today, causes fascination and fear, characteristics that are intrinsically associated with the Iyá Mi Oxorongá, who are deities who arrived in Brazil through the African spiritual diaspora. The intent of this work is to establish the relationship between the cult of the Iyá Mi with matriarchy and female power in candomblé, seeking out to understand the social and sacred role of priestesses in religious spaces, in addition to ratifying
\end{abstract}


the female's protagonism in the afro-brazilian religion. The qualitative approach was adopted to discuss the cosmogonic myths of creation of the world and of humanity through the deities Odudua and Obatalá. The theoretical framework based on the specialized literature sought books in Scholar Google and Scielo's papers. This analysis was complemented with the interpretation of the myth that appears in the first verse of itan 204 of the book "Mitologia dos Orixás" by Reginaldo Prandi which presents the female archetype of Iyá Mi, the Ancestral Witches associated with Odudua, the great Mother of Creation and matriarchal power of candomblé priestesses. One of the versions of the cosmogonic myth presents Odudua how the person responsible for gestating the world using Igbá$O d u$, the gourd of existence, and Obatala of making humanity appear. The cult of these deities is practiced in Brazilian candomblé yards, where the Odudua's figure is related with female ancestry and their ability to manager about life and death. In this sense, the Iyalorixás are women who stood out for assuming their faith to hold together the links of religious communities, which are spaces of resistance in the face of a culturally westernized and patriarchal society. The myth of the Iyá Mi is closely connected to this condition, emphasizing the sacred look of female power related to the condition of being a woman.

KEYWORDS: Sorceresses, Matrifocality, Myths, Female Power, Afro-Brazilian Religions.

\section{INTRODUÇÃO}

"As Senhoras dos Pássaros da Noite - Quando se pronuncia o nome de Iyá-Mi Osorongá, quem estiver sentado deve-se levantar, quem estiver de pé fará uma reverência, pois se trata de temível Orixá, a quem se deve apreço e acatamento" (AMADO, 2012, p. 32).

As religiões de matrizes africanas englobam uma afirmativa de que não há uma verdade absoluta, estabelecendo uma cultura com muitas especificidades que precisam ser reconhecidas, respeitadas e transmitidas (SIQUEIRA, 1995). No Brasil, a fértil construção promovida pela diáspora africana forçada levou ao caminho que possibilitou o surgimento do candomblé, onde essa cultura foi preservada (SERRANO e WALDMAN, 2007). É essencial perceber que o candomblé é um segmento religioso brasileiro e que não ocorre na África com a mesma estrutura organizacional que acontece no Brasil. É entendido como uma religião brasileira de matriz africana, uma vez que as divindades dos povos africanos se distinguem em diferentes níveis ritualísticos, sociais e de gênero nos terreiros brasileiros (BONINE, 2020). Nesse contexto, as mulheres de terreiro têm um lugar de destaque na condução do arcabouço religioso e cultural, uma vez que são detentoras do saber ancestral. Ocupam cargos de direção em suas comunidades religiosas e, muitas vezes, são preparadas desde muito cedo para liderar e levar adiante o modo de vida imaterial comunitário (SIQUEIRA, 1998). Desde as primeiras casas de candomblé a mulher foi protagonista 
devido à tradição étnica iorubá. Como mães de santo geraram e pariram a reinvenção da religiosidade africana no Brasil se colocando à frente na chefia espiritual das suas casas, independente da classe social de origem (SILVA, 2010).

O candomblé mais antigo do Brasil surgiu no início do século XIX numa área da cidade de Salvador na Bahia, chamada Barroquinha. Neste lugar se estabeleceu uma comunidade de ascendência iorubá denominada Candomblé da Barroquinha (Ilè Asé Airá Intilè), onde escravos africanos se encontravam para cultuar seus deuses. Esse espaço foi criado por lideranças femininas vindas das cidades de Oyó e Ketu, localizadas na atual Nigéria e República do Benim, respectivamente, e conduzidas forçadamente para o Brasil na condição de escravas. Iyá Detá, Iyá Kalá e Iyá Nassô foram princesas em seus territórios de origem e tiveram que lidar com a brutal condição que a escravidão impunha, não somente a privação da liberdade física, mas também a cultural e religiosa. Devido ao receio de perseguições que os cultos de origem africana sofriam na época, foi preciso mudar diversas vezes o local do terreiro para áreas mais afastadas. Estabeleceram-se de forma definitiva em terras arrendadas por Iyá Nassô, pertencentes ao Engenho Velho do Rio Vermelho de Baixo, onde se encontra atualmente a Casa Branca do Engenho Velho, o Ilê Axé Iyá Nassô Oká (MORIM, 2014; SANTOS, 2018). Essas mulheres viabilizaram a possibilidade nos Ilê (casa em iorubá) de formarem laços afetivos de solidariedade econômica, política e étnica (SILVA, 2010).

A partir dessa casa de candomblé, outros espaços sagrados de culto foram fundados em Salvador, todos dissidentes da Casa Branca, como o Terreiro do Gantois (Ilê Iyá Omi Axé Yámassê) e o Ilê Axé Opô Afonjá, sendo suas fundadoras iniciadas no culto aos Orixás no Terreiro da Casa Branca. Desde sua fundação até o momento atual todas essas casas sempre mantiveram na liderança feminina seu pilar central para a condução do cerimonial religioso. A transmissão desse comando acontece pelo jogo de búzios, que aponta quem deve assumir o posto, ou através de laços consanguíneos, como acontece no Terreiro do Gantois. Desta forma, essas casas mantêm a descendência matriarcal no cargo máximo de liderança do culto (SANTOS, 2018).

Ao longo de sua história, o candomblé foi atribuindo à mulher um papel notável de comando, o que se perpetuou ao longo das gerações. Coube ao matriarcado à responsabilidade da transmissão da tradição da prática religiosa, alcançando autoridade e respeito entre os adeptos, mesmo estando inseridas em uma sociedade opressora e misógina (BIRMAN, 1995). Em seu livro "A Cidade das Mulheres”, lançado em 1947, a antropóloga Ruth Landes mostrou o proeminente papel matriarcal exercido nos terreiros de candomblé 
BARROS, A. A. M.; AZEVEDO, V. A. M. Iyá Mi Oxorongá: olhares sagrados do feminino no candombé. Ethnoscientia v.6 n. 2, especial, 2021. DOI: 10.22276/ethnoscientia.v6i2.396

localizados na cidade de Salvador. Tamanha a relevância da presença feminina no comando desses terreiros, que seu livro apresentou essa Salvador como a "cidade das mulheres", fazendo referência às lideranças femininas do povo de santo (LANDES, 1967; MATORY, 2008).

A antropóloga Teresinha Bernardo (2005) ressalta essa postura de liderança através do conceito de matrifocalidade, no qual a estruturação familiar é centrada na figura materna, que é reconhecida como autoridade nessas relações. A figura masculina, quando existente, exerce um papel tangente nesse circuito, sem a possibilidade de ocupar o lugar central. De acordo com a autora, no candomblé a matrifocalidade determina a autonomia e preponderância da mulher na estruturação e manutenção do culto. Nessa religião a maternidade pode ser vivida de forma integral, em oposição à situação a qual estavam envolvidas suas antepassadas, que não podiam exercer plenamente essa etapa da vida. Eram obrigadas a cuidar dos filhos de suas sinhás, enquanto seus próprios filhos eram mantidos afastados e destinados à exploração. Assim tiveram a oportunidade de serem mães, mesmo que não biológicas.

A mulher preta sempre contou consigo mesma e com a rede matrifocal que a envolve para conseguir satisfazer as necessidades de suas vidas e famílias. O candomblé permitiu a essas mulheres uma nova perspectiva, uma vez que valoriza o trabalho feminino, proporcionando um redimensionamento do papel da mulher, tanto no aspecto religioso, quanto no social e familiar. Isso garante a reconfiguração da sua função, de modo que o candomblé acaba se estruturando, não apenas como uma possibilidade que a mulher preta tem para praticar sua religiosidade, mas também de atuar política e socialmente (SANTOS, 2018).

No contexto da matrifocalidade, as mulheres puderam ocupar distintos lugares nas cidades, se afastando do trabalho rural, e a partir daí atuar nos espaços públicos como escravas de ganho. Essas escravas tinham a permissão para realizar o comércio de produtos, o que promoveu o surgimento de um intenso sistema de trocas que existiu no período colonial brasileiro (SOARES, 2002). Tal movimento favoreceu a criação de uma rede que garantia seu trânsito e a aquisição de alguma renda, o que permitiu que muitas mulheres escravizadas conseguissem sua própria alforria e a de pessoas em seu entorno. O circuito de atuação gerado em torno dessas mulheres estabeleceu uma importante organização social feminina negra nessa época (SERRANO e WALDMAN, 2007).

Em muitas culturas no mundo o poder religioso é atribuído ao masculino, no entanto, nas comunidades religiosas afro-brasileiras ocorreu uma ruptura dessa hegemonia. 
Para compreender essa inversão é preciso buscar o papel histórico da liderança que as mulheres pretas exerciam como negociantes nas feiras iorubanas, ocupando a posição de grandes mercadoras. Essas feiras se apresentavam como um lócus destacado de uma variedade de trocas envolvendo bens materiais que vão além da barganha. Nestes espaços aconteciam permutas dos mais diferentes símbolos: notícias, modas, receitas, músicas, danças que promoviam um estreitamento das relações sociais, bem como a formação de importantes alianças. Estabeleciam-se laços afetivos, pois ali também ocorriam os namoros e acertavam-se os casamentos. A dinâmica da mulher iorubá ia além do exercício de atividades econômicas, ocupando uma posição de mediadora, não só das trocas de bens materiais, mas também as de domínios simbólicos. Esse lugar social ocupado por elas permitiu o aprendizado do exercício do poder para além da vida africana (BERNARDO, 2005).

Toda essa sabedoria ancestral se refletiu nas dinâmicas encontradas nas lideranças femininas dos terreiros brasileiros, nos quais o candomblé se fortaleceu como um espaço de resistência política frente a uma sociedade marcada pelo racismo religioso estrutural que ainda assola os praticantes de religiões de matrizes africanas. E o racismo é ainda mais destrutivo se esse adepto for mulher e preta. A mulher dentro dos terreiros exerce um papel estruturante de liderança, não somente no ritual litúrgico, mas também social, por promover a valorização da bagagem cultural ancestral e efetivar uma afirmativa essencial na transmissão de conhecimentos, principalmente em culturas de tradição oral. Os terreiros de candomblé passaram a se apresentar como um espaço efetivo de trocas e manutenção dessa cultura, além de favorecerem a ressignificação da herança social e coletiva das raízes africanas (JOAQUIM, 2001), permitindo à mulher um papel de destaque. Para Silva (2010), os terreiros são considerados territórios plurais e dinâmicos, por onde as relações de poder contraditórias perpassam e se articulam para garantir a possibilidade real da reafirmação étnica da negritude.

Parte do poder das mulheres está representado nas figuras das Iyagbás, as Orixás femininas que incluem: Iemanjá, Mãe dos Orixás e cujos filhos são peixes, Senhora das grandes águas, responsável pelo equilíbrio emocional; Oxum, Senhora das águas doces, governa a fertilidade feminina, dona do ouro e da vaidade; Oyá, Senhora dos raios e soberana dos espíritos dos mortos, governa os ventos e as tempestades, comanda a sensualidade feminina; Obá, Orixá que governa as correntezas dos rios e a vida das mulheres no cotidiano; Euá, Dona das fontes, do solo sagrado onde repousam os mortos, responsável por cultivar os jardins; Nanã, Guardiã do saber ancestral, Dona da lama que 
existe no fundo dos lagos e com a qual foi moldado o ser humano (PRANDI, 2001; VERGER, 2018). Seus poderes míticos mostram a essência complexa do que é ser mulher (RIBEIRO, 1996a). Essas Orixás estão relacionadas ao elemento água, normalmente associado à sensualidade e à feminilidade. $\mathrm{O}$ culto às águas doces ou salgadas remete ao simbolismo feminino e ao princípio do matriarcado, no qual a mulher se destaca como a progenitora (PORTILHO, 2019). Exceção é feita em relação a Oxalá (Obatalá), um Orixá masculino cujo principal ritual litúrgico nos terreiros nagôs é o "Awon Omi Osalá" (As Águas de Oxalá), que está ligado aos mitos iorubás de criação do mundo e da humanidade (PINHEIRO, 2008).

No mesmo contexto mítico das Iyagbás se apresentam as divindades chamadas Iyá Mi Oxorongá, as Feiticeiras Ancestrais cultuadas no candomblé. Representam a ancestralidade feminina, o poder feminino no mundo, simbolizando o útero sagrado que gerou toda a humanidade, assim como Exu é associado ao poder masculino. Estão vinculadas aos aspectos místicos da mulher em sua dualidade, expressando características protetoras e generosas, bem como aquelas perigosas e destrutivas (RIBEIRO, 1996b).

$\mathrm{O}$ presente artigo pretende apresentar a relação que existe entre às entidades iorubanas Iyá Mi Oxorongá com o exercício do matriarcado no candomblé, exaltando o papel da liderança feminina nessas comunidades. Através da análise do mito cosmogônico da criação do mundo, mostrar-se-á o poder feminino, simbolizado na figura das Iyá Mi como fonte para existência da humanidade. Resgatar a identidade de Iyá Mi é tarefa essencial, pois compreender seu papel implica na superação do preconceito de uma visão colonial estritamente redutiva e deturpada sobre o aspecto da ancestralidade feminina. Com intuito exploratório, esse artigo tem seu propósito embasado na discussão sobre o cenário da relação entre as divindades Iyá Mi Oxorongá e o sagrado feminino no candomblé.

No contexto social atual, no qual as lideranças religiosas continuam sendo vítimas do racismo estrutural e religioso, é essencial ressaltar a importância dessas mulheres e lhes dar maior visibilidade e respaldo, tendo como instrumento a força de um mito poderoso como o das Iyá Mi Oxorongá. A intolerância religiosa e a ignorância conceitual sobre os aspectos básicos das religiões brasileiras de matrizes africanas precisam ser descontruídas. Isso é necessário para que a comunidade de terreiro tenha seu direito constitucional de exercer sua fé com segurança garantido de fato. Respeito aos vários papeis exercidos por essas mulheres é um resgate histórico da construção de uma cultura tão diversa como a afro-brasileira. O preconceito e a intolerância devem ser combatidos e o conhecimento associado à diáspora africana divulgado cada vez mais. No século XXI apenas a oralidade 
não salvaguarda a tradição ancestral e as novas formas de assegurar esse conhecimento passam pelas palavras faladas, escritas e divulgadas. A ressignificação das deidades que fizeram a travessia espiritual transatlântica precisa ser discutida e interpretada para que o preconceito com o tema seja superado e o meio acadêmico tem uma importante contribuição nesse sentido. É uma maneira de proteger a comunidade religiosa de matrizes africanas e atingir a sociedade de forma geral. Informação é preponderante para acabar com o racismo e o preconceito em relação a tudo que veio da África e o mito das Iyá Mi Oxorongá é forte para isso.

\section{MATERIAL E MÉTODOS}

A abordagem qualitativa foi adotada neste trabalho para se compreender os fenômenos próprios das práticas e teorias religiosas afro-brasileiras e poder fazer a análise dos mitos cosmogônicos de criação do mundo e da humanidade. Através desse mito foi realizada a discussão do papel sagrado feminino associado às Feiticeiras Ancestrais Iyá Mi Oxorongá. O referencial teórico que fundamentou a argumentação escrita se baseou na literatura especializada sobre o assunto e que foi citada ao longo do texto. Incluiu livros que representam uma importante fonte do que já foi publicado sobre o tema e artigos científicos pesquisados nas bases de busca Google Scholar e SciElo. Foram utilizadas como descritores as palavras candomblé, candomblé e poder feminino, mitos e candomblé. A análise crítica textual discursiva apresentada é resultado da interpretação sobre o assunto à luz dos referenciais teóricos.

Várias são as versões associadas a um mesmo mito africano devido à religião ser uma prática familiar e local, o que torna as estórias múltiplas. Nesse artigo foi utilizado o mito das Iyá Mi Oxorongá que consta do livro de Reginaldo Prandi (2001), "Mitologia dos Orixás", e que reúne uma série de itans africanos. Em nagô itán quer dizer mito, que são contos, estórias de tempos imemoriais e lendas provenientes da cultura iorubá. Nos itans são descritos oralmente passagens da vida dos Orixás, seus feitos e sua estória de vida, que são transmitidos entre as gerações por meio de sua recitação. O itan 204 traz especificamente a passagem que trata das Feiticeiras Ancestrais, porém foi utilizado apenas o primeiro verso, aquele que apresenta as Iyá Mi. A escolha dessa passagem se deu por resumir as características essenciais para se entender a figura de Iyá Mi Oxorongá, assim como sua relação com o feminino. O verso foi numerado nas sentenças de 1 a 15 e separado em blocos de interpretação. Buscou-se interpretar e aprofundar o entendimento sobre o 
sentido dos períodos em que as características das Iyá Mi Oxorongá são ressaltadas para contrapô-las com a reflexão sobre o empoderamento feminino no candomblé.

Ao longo do texto as palavras citadas na língua nagô, àquela usada pelos iorubás, estão escritas em itálico. Nas citações referenciadas dos textos consultados procurou-se manter a grafia utilizada pelo autor, que pode ser diferente daquela utilizada no presente texto.

\section{RESULTADOS E DISCUSSÃO}

\subsection{A construção de uma mitologia sagrada}

Muitos povos africanos se amparam na oralidade como alternativa para perpetuar sua história e essa prática se mantém até a atualidade. Nos terreiros de candomblé a liturgia se reinventa diariamente e aquece toda a estrutura de comunicação que permite que esses espaços sejam vivos e atuantes. Nessa conjunção são conhecidos os poemas sagrados de Ifá, os itans. Na narrativa oral são estórias passadas de geração a geração para explicar diversas situações, principalmente àquelas que integram as energias dos Orixás, seus poderes e domínios. A tradição dos poemas de Ifá permitiu a formação do meio essencial para se entender a cosmologia, cultura, religiosidade, educação, poesia, dança, musicalidade, estrutura político-social, interações sociais, configuração do perímetro urbano, meio ambiente, relação com os ancestrais e a ciência praticada pelos iorubás (SOUZA e SOUZA, 2019). Eliade (1991) diz que ao recitarem os mitos, as pessoas compartilham a presença dos deuses e dos heróis, revivendo tempos imemoriais e grandiosos no seu cotidiano. E da mesma forma acontece com os poemas de Ifá. No entanto, ao se fazer a diáspora transatlântica espiritual para o Brasil, esses mitos foram sendo ressignificados na prática religiosa dos candomblés.

Nas mais diversas culturas africanas baseadas na oralidade, o mito agrega reflexões filosóficas, incorporando valores morais e culturais, que não são recontados como uma simples narrativa. Ao invés disso, esses mitos são atrelados à prática religiosa e retransmitidos às gerações dentro da rotina sagrada. A oralidade e a mitologia constituem elementos que favorecem a construção das relações entre a sociedade e o sagrado, incluindo a interpretação do mundo às formas de viver. Ao serem repetidos e recontados, os mitos funcionam como mecanismos cosmológicos para o entendimento de aspetos da sociedade: o natural, o econômico, o político e o social. Sendo assim, o conhecimento e a tradição não são armazenados apenas na forma escrita e nos arquivos, mas revividos e realimentados permanentemente. São transmitidos através da palavra, sendo esta atuante e condutora do 
poder do axé, a força vital sem a qual não existe vida ou movimento. Sem o axé o culto não pode ser realizado. Dessa maneira, o conhecimento passa a ser vivo e guardado pelos indivíduos mais sábios de uma geração, configurando uma sabedoria iniciática. Esse saber deve ser difundido entre os adeptos que passaram pelas obrigações de iniciação na religião dos Orixás (SANTOS, 2012). A iniciação no candomblé é a vinculação da vida de uma pessoa à religião para "fazer o santo" e se conectar a divindade regente do seu ori (cabeça), passando o Orixá a agir permanentemente no seu dia a dia. Significa fazer a ligação da vida física ao mundo sobrenatural e com isso ter acesso ao conhecimento secreto, disponível apenas para os adeptos ao longo dos anos e etapas da formação no candomblé. (KILEUY e OXAGUIÃ, 2014). A pessoa a ser iniciada é escolhida pela divindade e, ao aceitar essa parceria, irá passar por vários rituais litúrgicos para que possa ser sacralizada (COSSARD, 2006).

A cultura iorubana, em específico, teve uma marcante oralidade em sua tradição religiosa, na qual os mitos e a memória coletiva desempenharam notório papel-chave na compreensão de suas realidades históricas. Durante muito tempo, as interpretações da tradição oral foram as principais referências de conhecimentos acerca da trajetória dos iorubás no tempo e no espaço. Esse complexo mitológico foi preservado nos países que receberam a diáspora africana, especialmente no Brasil (ARAÚJO, 2016), e transcenderam a oralidade, visto que grande parte desse conhecimento atualmente possui uma narrativa literária escrita em diferentes meios de comunicação e mídias modernas.

Embora o continente africano tenha uma vasta heterogeneidade étnico-cultural que varia de aldeia para aldeia, de maneira geral e desde tempos imemoriais, a oralidade é a forma que o povo africano utiliza para se expressar, manter suas tradições, ensinar e transmitir valores. Dessa forma, resguardavam as especificidades de cada etnia retratada em contos, mitos e estórias. Seus descendentes que vieram para o Brasil conservaram essa fonte de suas culturas tradicionais para manter e reconstruir sua ancestralidade. Até os dias atuais, a maior parte das sociedades afrodescendentes considera fundamental o exercício da oralidade, do conhecimento adquirido, transmitido de geração para geração por meio das palavras proferidas pelos guardiões da tradição oral, que conhecem e conduzem as ideias sobre diversos temas (DUARTE, 2009). Sobretudo os que interessam a essa análise, ou seja, a relação ser humano-natureza e os fatos históricos vividos pelas mulheres da comunidade em questão. 


\subsection{As Iyá Mi Oxorongá, as feiticeiras iorubás}

As Iyá Mi são divindades complexas, representadas na forma feminina da lua, pois das entranhas das mulheres é de onde vem tudo para o mundo. São as Mães Ancestrais que originaram a humanidade e têm o domínio de decidir sobre a vida de seus filhos, seu direito de nascer ou não. Por isso são tratadas não só como Senhoras da Vida, mas também como Senhoras da Morte, que é a consequência da vida. Cultuar as Iyá Mi é cultuar os antepassados, uma vez que os mortos seriam os mediadores entre os humanos e o mundo sobrenatural. Os mortos teriam o papel de acessar a orientação e o poder, no entanto, a morte em si não o habilita a se tornar um ancestral. É preciso apresentar valores morais e distinção social em vida para serem aptos a orientar seus descendentes. Assim, as Mães Ancestrais são atemporais por entenderem os segredos da vida e podem manipular pela magia o nascimento e a morte (PRANDI, 2001). Não é possível controlar o poder das Iyá Mi, uma vez que é necessário esse poder fluir livremente no mundo e cumprir seu papel nutridor (SANTOS, 2008).

No aspecto mais amplo do seu arquétipo, pode-se relacionar a figura mitológica das Iyá Mi com o conceito de sororidade, no qual os laços de cooperação que unem as mulheres dão apoios para a construção da unidade feminina. Nesse sentido, é possível tangenciar a posição exercida por essas entidades junto aos grupos femininos de trabalho organizado como, por exemplo, as diversas cooperativas das quebradeiras de coco babaçu, o Movimento de Mulheres Camponesas e o Movimento de Mulheres Trabalhadoras Rurais. Essas mulheres são protagonistas em questões ambientais, políticas e sociais, preparadas e combativas nas reivindicações de direitos individuais e coletivos (SILVA, 2017). O cooperativismo entre elas gera uma economia solidária que mantêm suas famílias, formando uma rede organizada de subsistência.

Iyá Mi também está representada nas quituteiras de tabuleiro e nas vendedoras de acarajé, mulheres de múltiplas habilidades que trazem como herança tradições e práticas de suas antepassadas. Dominam a arte da cozinha ao confeccionar iguarias e são hábeis na venda de seus produtos, além de exercerem uma boa oratória para conquistar compradores (MARIOSA e MAYORGA, 2018). Essa é uma aptidão que relembra a ancestralidade da mulher preta na África enquanto grandes negociantes nos mercados populares. Quando mulheres de terreiros se reúnem para a feitura das comidas ritualísticas, elas têm no espaço urbano das casas de candomblé um território próprio de trocas e sociabilidades que vão além das necessidades litúrgicas. Contribuem com a força do trabalho comunitário para o 
funcionamento do terreiro e compartilham a comida produzida com todos que participam do culto aos Orixás. O mito das Iyá Mi está presente em todas essas situações, pois expressa a forma como o feminino ocupa seu espaço social.

As Iyá Mi são chamadas de Ajés (Feiticeiras), como referido no itan iorubá. O mito das Velhas Feiticeiras está relacionado à percepção africana de que o ganho de conhecimento e a sabedoria só vêm com a idade, ou seja, com a experiência de vida. E para manter a memória da sabedoria associada às Ajés, nas casas de candomblé as sacerdotisas das Feiticeiras são responsáveis pelo seu culto. Esse cargo litúrgico corresponde a Iyalodê, aquela que distribui o axé das Iyá Mi para a comunidade de santo (D’OBALUAYÊ, 2013). É um título honorífico que ressalta o poder feminino ancestral (SILVA, 2010). A feitiçaria é pensada em algumas culturas como um aspecto antissocial, entretanto, na sociedade iorubá tradicional as Ajés não são malquistas e compõem um suporte essencial para a comunidade. É necessário se evitar falar mal delas, pois possuem uma força agressiva e perigosa. É preciso ter para com elas comportamentos prudentes e reservados, uma vez que não há quem resista aos seus ebós fatais. Todo cuidado é pouco com essas feiticeiras, pois elas exigem o máximo de respeito (VERGER, 2018). Ebó (ébô) para os iorubás significa presentear, sacrificar, é o princípio do axé, uma vez que através dele a força vital se fortalece e pode ser difundida (KILEUY e OXAGUIÃ, 2014).

Também são conhecidas na prática litúrgica por outros nomes como: Iyá Mi Agba Minhas Mães Ancestrais, ratificando a ideia em torno da atemporalidade do seu culto; Iyá Mi Ajé - evidenciando sua relação com a prática de feitiços e sortilégios; Iyá Mi Odu relacionando o poder feminino à Odùduwà, também conhecida como Odùa, importante personagem mitológica da cultura iorubá. Representa o Orixá feminino ligado a Igbá-Odu, a cabaça da existência, vinculada à mitologia da criação do mundo e de onde surgiu a humanidade (D’OBALUAYÊ, 2013). Iyá Wón, título que lhe foi concedido por Olorum e que faz referência à criação do mundo como a Mãe de Todos para a eternidade. Sem Iyá Wón nada pode ser feito pelos homens. Seu poder é imenso e deve ser usado com parcimônia, assim foi recomendado por Olorum, o Deus Supremo. Em troca de proteção e orientação, as Iyá Wón exigem oferendas. Para aqueles que forem mal agradecidos ou impertinentes, tudo lhes será tomado, além de sofrerem a perseguição das Ajés (BENISTE, 2016). É exigido por elas respeito às mulheres e ninguém quer evocar a ira descontrolada dessas divindades, porque as forças que elas possuem têm a capacidade de dar a vida e a morte. Além disso, ser temperamental é uma das condições da personalidade das Iyá Mi. 


\subsection{As Iyá Mi Oxorongá e o mito da criação do mundo e da humanidade}

É possível encontrar na literatura muitas versões para o mito cosmogônico iorubá (PRANDI, 2001; COSSARD, 2006; MARTINS, 2012; SANTOS, 2012; OXALÁ, 2014; BENISTE, 2015; 2016; NOGUEIRA, 2018, VERGER, 2018). Com a interpretação de diferentes estórias foi possível identificar os pontos em comum e as divergências para poder apresentar a estória a seguir. Da mesma forma que na narrativa iorubá não existe uma verdade absoluta, nessa análise apresentada também não se tem essa pretensão. Então não representa uma estória final, mas sim uma estória fruto das diferentes formas de se contar como o mundo e a humanidade passaram a existir a partir da perspectiva de um povo africano.

Na mitologia iorubá, antes de tudo, o universo era formado apenas pelo Orun e o Mar. O primeiro relacionado à terra divina, feito de ar, onde vive Olorum (Olodumare ou Olofin), o Dono do Destino e do mundo sem fim. O segundo é feito de água e é habitado pela misteriosa deusa Olokun, aquela que vive nas regiões mais profundas e não se deixa conhecer. Dessas duas divindades nasceram Obatalá (Obàtálà ou Òrisàlá) e Odudua (Odùduwà) e depois os demais Orixás, que representam as forças da natureza e simbolizam os atributos da personalidade humana.

Olorum é o único dotado de alabalaxé, ou seja, o poder de criar a vida, de definir seu propósito e realizá-lo. Essa divindade sagrada encarregou seus filhos primogênitos de iniciarem uma jornada de conhecimento para criação do mundo. A Obatalá coube à liderança dessa tarefa e junto com ele foram sua irmã Odudua e os demais Orixás. Todos com uma incumbência estipulada por Olorum, exceto Odudua. Ao ser questionado por ela, recomendou que seguisse Obatalá e o apoiasse no que fosse preciso. Nada devia temer, pois seu papel na criação estava reservado. Olorum advertiu a Obatalá que não aplacasse a sede com bebida fermentada e que consultasse Orumilá (Senhor dos Segredos e Caminhos, o conhecedor do Ifá) para saber como proceder na missão. No entanto, tomado de orgulho, ignorou a recomendação e iniciou imediatamente a jornada. Cansado e com sede, ele aceitou a seiva de palma oferecida por Exu e adormeceu. Diante da falha de Obatalá, Olorum concedeu a Odudua o protagonismo dessa jornada (BENISTE, 2016; NOGUEIRA, 2018).

Com humildade e de acordo com a vontade de seu pai, Odudua consultou Orumilá, que lhe orientou a partilhar essa tarefa com outros Orixás e a utilizar a cabaça da existência (Igbá-Odu), pois só através dela poderia triunfar em sua jornada. Na cabaça encontravam-se quatro cabaças menores que continham os elementos fundamentais para criação do mundo: 
ar, terra, água e fogo. Com Ogun abrindo os caminhos, Odudua chegou aos limites do Orun, abriu a cabaça e retirou um recipiente com um pó branco. Soprou e fez surgir uma pomba branca que transformou, através dos ventos, as trevas em céu azul, onde Oiá criou a atmosfera (ar). De outro recipiente soprou um pó azul e de um caramujo brotou água, na qual Iemanjá e Oxum trabalharam para formar os oceanos, os rios, lagos, lagoas e cachoeiras. Após soprar o pó preto do terceiro recipiente, com a galinha-d'angola, Xapanã moldou a terra em vales, morros e montanhas. Por fim, do pó vermelho soprado apareceu um camaleão que soltava fogo, com o qual Aganju cozinhou as entranhas da terra. E assim Odudua gestou e gerou o mundo, designando Oxóssi e Aroni a enchê-lo com as plantas e os animais que viveriam nas florestas. A Obatalá restou moldar e dar vida a humanidade que habitou o mundo junto com os Orixás em tempos imemoriais (MARTINS, 2012; BENISTE, 2015; NOGUEIRA, 2018).

Odudua é a representação deificada das Iyá Mi, que simboliza coletivamente as Mães Ancestrais e o princípio feminino de onde tudo se origina e Odú corresponde a Obatalá ou Oxalá, que é o princípio masculino. Odudua e Obatalá referem-se à relação entre os arquétipos feminino e masculino, a partir dos quais a vida foi concebida. Esses conceitos e divindades são simbolizados pela cabaça ritual Igbá-Odu, que representa o universo, onde a parte superior é de Obatalá e a inferior é de Odudua, a responsável por impulsionar a continuidade da existência (SILVA, 2010; SANTOS, 2012; OXALÁ, 2014).

O culto das Iyá Mi, o mais antigo das mulheres, é feito na cabaça, fruto da árvore cabaceira ou árvore-de-cuia (Crescentia cujete L. - Bignoniaceae), cuja forma arredondada remete ao ventre da mãe (BARROS, 2011). Essa espécie é originária da América tropical e Antilhas (LORENZI et al., 2003), porém Barros e Napoleão (1999) dizem que pode ser encontrada na África. O uso litúrgico da Igbá-Odu é relacionado ao assentamento das Iyá $\mathrm{Mi}$, onde se colocam as oferendas para as Ajés no fruto e também se usa a cuia como utensílio (JAGUN, 2019). A cabaça igualmente representa o útero da mulher, associada diretamente ao simbolismo do nascimento da humanidade. Das entranhas da cabaça surgiu o povo que habita a Terra (SANTOS, 2012).

É vedado a mulher olhar para a cabaça, pois se o fizer poderá ser punida com a morte ou ficará cega, assim determinaram as Iyá Mi. A adoração da Igbá-Odu é exclusiva dos sacerdotes de Orumilá, os Babalaôs, que praticam o culto a Ifá-Orumilá, que é patriarcal. Já as mulheres se reúnem na sociedade secreta matriarcal Geledé, que expressa o poder feminino sobre a fertilidade, a procriação e o bem estar da comunidade pelas quais são responsáveis. As dirigentes do culto têm o título de Erelu e presidem os rituais onde se 
dança para aplacar a ira das Iyá Mi. Na tradição nagô-iorubá é permitida a participação de homens nas cerimônias, porém apenas usando as máscaras Guélédé e vestidos como mulheres (SILVA 2010; MARTINS, 2012).

O itan Atowódówó conta as estórias dos mitos cosmogônicos que revelam o processo de criação do mundo e a separação entre o Òrun (mundo sobrenatural) e o Aiyé (mundo terreno). O Òrun representa o mundo imaterial, habitado pelos ará-òrun, que são divindades. O Aiyé é a parte física da existência, onde vivem os seres naturais chamados de aráyé ou ará-àiye, ou seja, a humanidade, os animais, vegetais e minerais. $\mathrm{O}$ formato arredondado de cabaça também está associado à forma perfeita do mundo, quando o Òrun e o Aiyé ainda permaneciam ligados, pois nos primórdios não existia a separação entre esses espaços (BARROS e NAPOLEÃO, 1999; BENISTE, 2015).

A cabaceira é uma árvore que tem importância simbólica na mitologia iorubá e em vários aspectos culturais desse povo. Tanto que está relacionada ao mito cosmogônico da formação do mundo. A cabaça estabelece a união do masculino, representado pela parte superior do fruto, que é ligado a Obatalá, com o Òrun, com a parte inferior, associada ao feminino e à Odudua, o Aiyé. O contato entre essas duas metades mantém o equilíbrio no universo. A interação harmoniosa entre os poderes masculino e feminino permite a manutenção estável do universo e a continuação da existência nos dois níveis fundamentais (SANTOS, 2012; D’OBALUAYÊ, 2013).

\subsection{O poder feminino das Iyá Mi Oxorongá}

No itan que trata do mito das Iyá Mi Oxorongá, Prandi (2001) apresenta essas divindades relacionadas ao poder feminino coletivo, pois as feiticeiras são consideradas a representação da força mítica da mulher, manifestada na possibilidade de gerar filhos e povoar o mundo:

"Iá Mi chegam ao mundo com seus pássaros maléficos ${ }^{1}$ As Iá Mi Oxorongá são as nossas mães primeiras, ${ }^{2}$ raízes primordiais da estirpe humana, são feiticeiras. ${ }^{3}$

São velhas mães-feiticeiras as nossas mães ancestrais. ${ }^{4}$ As Iá Mi são o princípio de tudo, do bem e do mal. ${ }^{5}$ São vida e morte ao mesmo tempo, são feiticeiras. ${ }^{6}$

São as temidas Ajés, mulheres impiedosas. ${ }^{7}$ As Oxorongá já viveram tudo o que se tem para viver. ${ }^{8}$ As Iá Mi conhecem as fórmulas de manipulação da vida, ${ }^{9}$ para o bem e para o mal, no começo e no fim. ${ }^{10}$ Não escapa ileso do ódio de Iá Mi Oxorongá. ${ }^{11}$

O poder de seu feitiço é grande, é terrível. ${ }^{12}$ Tão destruidor quanto é construtor e positivo o axé, ${ }^{13}$ 
BARROS, A. A. M.; AZEVEDO, V. A. M. Iyá Mi Oxorongá: olhares sagrados do feminino no candombé. Ethnoscientia v.6 n. 2, especial, 2021. DOI: 10.22276/ethnoscientia.v6i2.396

que é a força poderosa e benfazeja dos Orixás, ${ }^{14}$ única arma do homem na luta para fugir de Oxorongá.",15

(PRANDI, 2001, p. 348)

$\mathrm{Na}$ primeira sentença do itan é destacada a associação das Feiticeiras com os pássaros, o que dá a elas o título de Eléye (Senhoras dos Pássaros), em referência a sua relação com as aves noturnas e as aves de rapina. Através de seus pássaros transmitem o axé, tornando-se detentoras e condutoras dessa energia sobrenatural. O termo Oxorongá vem do nome de um pássaro africano que emite um som gutural que simboliza sua cólera. Os pássaros se posicionam sobre os pés e mãos das Iyá Mi. Eles são os agentes do poder das Senhoras dos Pássaros devido a sua capacidade de locomoção rápida, o que os tornam mecanismos perfeitos para levar a desgraça ou a felicidade. Permitem às Feiticeiras viajarem livremente entre os mundos material e espiritual. A coruja também é um de seus pássaros, que pousa suavemente nos tetos das casas e silenciosamente leva os feitiços até seus destinos. De acordo com a vontade de uma Ajé: "Se ela diz que é pra matar, eles matam, se ela diz pra levar os intestinos de alguém, levarão" (SANTOS, 2008).

Nas sentenças 2, 3 e 4 é notado seu papel maternal, no qual as Iyá Mi são as Mães Ancestrais que geram e dão vida à humanidade. Essas Senhoras da Vida e da Morte detêm esse grande poder e são temidas por isso. Todos os indivíduos devem suas vidas às Iyá Mi, materializadas e sacralizadas na figura materna (RIBEIRO, 1996b). Essas entidades genitoras ancestrais guardam o segredo da criação, sendo seu maior fundamento expressado na capacidade de dar a vida (D’OBALUAYÊ, 2013). Essa é uma importante relação com o papel da mulher que gesta, concebe e cuida de seus filhos.

A partir das características arquetípicas expostas na análise do mito (poder, controle, ira e maternidade), percebe-se uma conjunção de todas essas características nas Iyagbás cultuadas no Brasil. Essas Orixás representam a síntese de todas as particularidades da personalidade feminina, retratadas em Oxum, que possui o domínio da fertilidade humana; Oyá representada na ira e a relação com o culto dos mortos; Obá, a terrível amazona belicosa; Iemanjá, que rege a atividade maternal; Nanã, ligada à morte e à figura da anciã; Euá, a Senhora do Segredo, mostrando que nem tudo pode ser revelado. Dessa forma, congregam a alma de todas as mulheres juntas, conduzidas pela força das grandes Mães Ancestrais (KILEUY e OXAGUIÃ, 2014).

Percebe-se no mito das Iya Mi Oxorongá uma dualidade marcada entre o bem e o mal. Esse caráter se reflete na personalidade das pessoas que podem transitar entre esses 
dois horizontes morais. Outra característica que mostra esses dois lados da divindade é sua ligação com a raça humana, pois são as Mães Ancestrais que transitam entre os meios natural e sobrenatural. Viajam facilmente entre os diferentes planos que compõem a divisão espacial na cultura iorubana, mesmo após a separação que dividiu o mundo sobrenatural do terreno. Essa associação entre dois lados antagônicos também está simbolizada na forma redonda da cabaça Igbá Odu, que guarda os aspectos duos da existência. Essas Senhoras, quando devidamente cultuadas, apresentam seu aspecto voltado para o bem. Precisam ser agradadas para terem bons sentimentos e tornarem possível que coisas boas aconteçam, o que é associado à característica materna de amar seus filhos. Em contraponto a vida está à morte e a partir daí exercem também seu poder para retirar a vida, quando têm maus sentimentos.

No próximo bloco, nas sentenças de 5 a 7, é apresentada uma face das Ajés que mostra sua relação com os ancestrais. Como podem viajar entre os diferentes planos do mundo, conseguem conectar os viventes aos mortos que transcenderam. É um caráter interessante da sociedade iorubá, vinculado ao respeito pelos mortos e a necessidade de se comunicar com os ancestrais em busca de orientação e sabedoria. Esse saber não se perde com o fim da vida, mas se renova constantemente através dos descendentes que mantém os costumes e as crenças.

Nas sentenças 8 a 11 observa-se a relação das Iyá Mi com mulheres mais velhas. Isso marca uma característica primordial da cultura africana, ou seja, de que a sabedoria é acúmulo de poder e isso acontece com o avanço da idade, com a experiência de vida. Desta forma, as Mães Ancestrais, por terem vivido muito, são reconhecidas pelo conhecimento que adquiriram em sua existência. Esse poder e o respeito feminino estruturaram o candomblé no Brasil, percebido nas figuras das primeiras Iyalorixás (iyá, mãe em iorubá). Essa religião é fundamentada numa organização totalmente hierarquizada, onde os conhecimentos e ensinamentos são revelados ao longo dos anos, a partir da iniciação no culto aos Orixás. Muitos dos conceitos se sustentam através da autoridade religiosa e hierarquia no sacerdócio, associado à experiência de vida, aprendizado e sabedoria sobre a liturgia e as divindades.

No último bloco, entre as sentenças 12 a 15, percebe-se um aspecto sobrenatural presente no arquétipo simbólico construído em torno das Iyá Mi Oxorongá, a relação com a feitiçaria. O poder de realizar todo o tipo de sortilégio para promover a construção do axé capaz de destruir e retirar a vitalidade de quem não tem merecimento para tal. De acordo com Verger (1994), a feitiçaria faz parte da dinâmica iorubá no cotidiano das relações 
sociais e seu exercício se conecta com o modelo simbólico das Ajés. No culto de Iyá Mi os membros da sociedade devem evitar acordar sua força agressiva, sempre se referindo a elas com prudência. Esses versos mostram que a única forma de aplacar toda essa cólera seria estar vinculado aos Orixás. Somente essa conexão seria capaz de conter seu caráter agressivo, evidenciando a necessidade da humanidade de estar em contato com as divindades e sua natureza simbólica para que possam fugir da ira de Oxorongá.

\section{$3.5 O$ matriarcado no candomblé e a construção do empoderamento feminino}

A força e o poder das Iyá Mi estão diretamente relacionados ao papel de liderança exercida pela mulher no candomblé que, através do processo histórico, foi um dos principais focos de resistência dos africanos e seus descendentes no Brasil. A figura mitológica das Ajés reúne características que estão associadas ao processo de empoderamento feminino. A sabedoria, a capacidade de gerar a vida, de lidar com as dualidades, da persistência em impor sua vontade, a habilidade de tomar decisões, a necessidade de ser valorizada enquanto líder e mulher, a mistura de diferentes sentimentos para o bem ou para o mal. Tudo isso evidencia a construção do arquétipo simbólico associado às Iyá Mi. Essa conjuntura é expressa pelas Iyalorixás, que são o alicerce da cultura religiosa do candomblé. Podem-se observar relevantes valores do arquétipo assumido por elas na maneira como exercem seu trabalho na coordenação e proteção do culto. Isso se deve as suas relações sociais como líder comunitária, religiosa e mediadora. Essa liderança é o núcleo principal de suas casas (JOAQUIM, 2001; CARNEIRO e CURY, 2008).

Nesse contexto, mulheres pertencentes à classe social mais pobre, principalmente as negras, podem ocupar altos cargos, diferente da condição encontrada em outras religiões (SILVA, 2010). É possível às sacerdotisas do candomblé apresentarem um comportamento autônomo, de independência e empoderamento nas comunidades que dirigem. Essas mulheres desenvolveram historicamente o protagonismo em seus territórios de vivências e, desde o final do século XIX, conquistaram seu espaço social, enfrentando o machismo e o racismo nas suas práticas cotidianas (MARIOSA e MAYORGA, 2018). Fato esse que é mais do que atual, pois a sociedade brasileira pouco mudou em relação a essas questões. Com o recrudescimento do preconceito religioso (SILVA, 2007) é preciso fortalecer a convicção de que apenas a sororidade entre essas mulheres não é suficiente, mas deve envolver toda a sociedade. É preciso que tenham visibilidade para fortalecer o 
enfrentamento constante contra o racista e o machismo e a misoginia, além de ressaltar a luta antirracista.

A resistência ao preconceito racial, cultural e religioso expressado por essas sacerdotisas é uma forte representação da herança matriarcal no candomblé, que foi algo imposto pelo próprio regime escravocrata. É difícil pensar que os homens escravizados tivessem a possibilidade de levar adiante a prática sacerdotal nesse contexto histórico. Enquanto a maioria dos homens negros era destinada a trabalhar nas fazendas, se ocupando principalmente do trabalho braçal e da prática agrícola, as mulheres escravizadas conseguiram se encaixar nas mudanças sociais e econômicas do período colonial. Por serem forçadas a exercerem as mais diversas atividades domésticas e comerciais nos centros urbanos tiveram uma espécie de "livre trânsito" entre a casa e a rua, fato que permitiu a circulação feminina escravizada nos espaços públicos. Isso também possibilitou, de forma secreta, manter a prática do culto aos Orixás (SANTOS, 2018).

O trabalho como escravas de ganho com a venda de frutas, hortaliças e quitutes, nos conhecidos tabuleiros de ganho, nas feiras livres e nas ruas das principais cidades do país, fez com que essas mulheres transitassem pelo núcleo central do comércio. Nestes locais aconteciam as trocas materiais e simbólicas da sociedade escravocrata. Isso propiciou uma experiência comercial diferenciada das atividades exercidas pelos homens negros, explorados por sua força braçal. O acúmulo de capital monetário por essas mulheres foi preponderante na compra de cartas de alforria e no surgimento de pequenos negócios locais que promoviam o sustento das famílias libertas. Esse núcleo social ficou profundamente conectado à tríade figura da mulher-mãe-provedora. A logística do valor das trocas é antiga e evoca a liberdade de circulação e o destaque nos negócios obtidos pelas mulheres iorubanas na África, uma tradição que se adaptou e continuou no Brasil (BERNARDO, 2005; NOVAES, 2017). Com a abolição oficial da escravidão em 13 de maio de 1888, a mulher preta ganhou de vez os espaços públicos vendendo seus produtos, enquanto as mulheres brancas permaneceram aprisionadas no espaço doméstico (SILVA, 2010), como estabelecia a sociedade patriarcal da época.

Na cidade do Rio de Janeiro, em meados do século XIX, por exemplo, as escravas chamadas "negras minas" praticaram esses serviços de ganho nas ruas e foram as principais responsáveis por obter suas próprias alforrias e de outros escravos. Principalmente por aquelas diretamente provenientes da África e que já tinham experiência nessas atividades como mercadoras em suas comunidades originais (FARIA, 2011). Essas mulheres movimentaram o comércio de rua nos espaços urbanos carioca, exercendo o protagonismo 
na mudança da relação social e econômica com a sociedade escravocrata luso-brasileira. Segundo Silva (2010), as negras de ganho estão representadas nas famosas quituteiras, compondo até hoje a geografia humana e econômica de cidades urbanas como Salvador na Bahia, por exemplo.

É sabido que a maior parte das religiões estabelecidas é comandada apenas por homens, ou estes desempenham um destacado papel na hierarquia. Um exemplo disso é no catolicismo onde, apesar da imensa maioria de fiéis serem mulheres, elas não são responsáveis por cargos de destaque na estrutura religiosa. No caso das religiões afrobrasileiras, essa perspectiva muda, pois as mulheres assumem postos de liderança, alcançando os serviços mais altos na hierarquia religiosa (TORRES, 2015), como um reflexo do processo histórico de construção dessas religiões no Brasil. A luta e resistência dessas mulheres fizeram a história acontecer e conquistaram seu espaço nos terreiros, abrindo caminhos sem se intimidarem diante dos desafios. Atuam constantemente desenvolvendo estratégias de enfrentamento para desconstruir a invisibilidade que o racismo e o machismo alimentam (MARIOSA e MAYORGA, 2018).

Todo esse protagonismo foi conquistado ao longo das gerações e de forma coletiva através de um conjunto de redes de apoio formado por mulheres para auxiliar o grupo no qual estavam inseridas. Nesse sentido, o processo de conquista do espaço das mulheres a frente de suas comunidades religiosas dialoga com o conceito de empoderamento feminino. Essa condição está representada numa das mais importantes personalidades negras que viveu no Brasil entre o final do século XIX e início do XX e que foi Tia Ciata. A partir de sua liderança comunitária surgiu um espaço na cidade do Rio de Janeiro que fícou conhecido como "Pequena África". Sua atuação e acolhimento ajudaram a transformar esse território num polo de resistência e exaltação ao culto aos Orixás, através da articulação cultural que ela promovia em sua casa. Também em destaque é o papel das irmandades religiosas negras, em especial a Irmandade de Nossa Senhora da Boa Morte, na cidade de Salvador, formada apenas por mulheres pretas, que organizaram um importante local de solidariedade e resistência racial, cultural e religiosa do povo negro (BERTH, 2019; BERTH et al., 2020).

Ao longo dos anos, muito se modificou em relação à história e ao papel da mulher nas sociedades ocidentais. As diferenças entre homens e mulheres eram reforçadas, comprovadamente, pelas diferenças culturais e não biológicas apresentadas em cada sociedade. Na sociedade iorubá a família é protagonizada pela mulher e a mais velha é quem toma as decisões, definindo toda a dinâmica doméstica. A mulher iorubana é múltipla 
e exerce diversas posições sociais: mãe, esposa, filha, sacerdotisa e bruxa. O maior valor é dado à mulher como mãe porque os iorubás reverenciam a maternidade (MAKINDE, 2004). Um aspecto que ressalta o conceito de matrifocalidade nessa comunidade. Ao homem cabe o papel de guerreiro, associado à força física masculina, além da gestão das atividades públicas (NOGUEIRA, 2018).

Ao manterem uma constante ação pelos seus direitos, as mulheres foram alcançando espaços que lhes foram negados por determinações de uma sociedade patriarcal, machista e misógina, cuja representação maior é ocupada por homens (TORRES, 2015). A simbologia de Iyá Mi Oxorongá rompe com esse processo de anulação pelo qual as mulheres passaram historicamente, uma vez que as Ajés não se curvam a ninguém, seu poder e presença são imensuráveis, estando à presença masculina destrutiva subjugada a elas.

\section{CONCLUSÕES}

A existência da cultura africana no Brasil deu-se, em primeiro lugar, pela sobrevivência dos seus cultos que conseguiram atravessar o Oceano Atlântico e se reestruturaram, ganhando uma identidade diferente daquela praticada na África, porém baseada na sua origem. A diáspora africana forçada teve no candomblé o seu elo cultural, não permitindo que o processo de ruptura fosse total. Assim, no Brasil, a religião funcionou como o principal elemento de afirmação dessa identidade.

A continuidade cultural e religiosa só foi possível pela ação determinada de mulheres escravizadas que mantiveram as representações simbólicas africanas através do candomblé. Nessa comunidade os mitos são reais para quem as vive na sua prática cotidiana. Os símbolos culturais e religiosos são cultivados e renovados a partir da presença e do trabalho dos praticantes, principalmente de mulheres. Suas vozes de resistência ecoam no interior de seus templos, exercendo distintas funções como líderes religiosas e comunitárias, mães e educadoras. São agentes de um processo árduo de sobrevivência frente a quatro séculos de perseguições.

Através da análise dos arquétipos religiosos foi possível traçar a longa trajetória feminina na afirmação da identidade afro-brasileira do ponto de vista da mitologia dos iorubás. Nesse sentido, os contos de ifá, passados através da oralidade, mostram a sobrevivência de toda uma epistemologia que foi mantida, transmitida e ressignificada no Brasil. O valor dos itans nesse processo é ressaltado por fornecer, a partir de seus versos, ensinamentos que são usados pelas comunidades de candomblé e fazem a ligação com a ancestralidade africana. Permitiu que os mitos mantivessem unidos os laços culturais e 
religiosos da origem geográfica e que não fossem esquecidos, mas reafirmados através das palavras, dos cânticos e do toque dos atabaques. Esse conhecimento preservado fez com que a diáspora não fosse apenas física, mas também espiritual, possibilitando a travessia transatlântica das divindades que salvaram seu povo do esquecimento da sua história. Houve uma distensão, mas não um rompimento total, possibilitado pela ação de mulheres que não permitiram que a África fosse apenas uma lembrança perdida ao longo dos séculos de escravidão e sofrimento.

Essa força feminina foi analisada em relação ao mito das Iyá Mi Oxorongá, deidades que não devem ser entendidas como maléficas, mas sim como extraordinariamente poderosas, ainda mais estando associado à questão feminina. Sua narrativa mitológica é forte e pode levar a uma ideia ameaçadora, o que deve ser entendido como uma fortaleza para a mulher atual. Iyá Mi se apresenta dessa maneira, reforçando a necessidade de se respeitar os espaços conquistados pelas mulheres no âmbito religioso do candomblé e expandi-lo, o que permitiria que ocupassem outras posições de relativo prestígio social para além dos terreiros. Negar isso às mulheres é inaceitável do ponto vista das Iyá Mi.

Conforme o que foi exposto, evidencia-se o protagonismo do gênero feminino nas comunidades afro-religiosas brasileiras, onde a figura simbólica de Iyá Mi Oxorongá nutre as lideranças litúrgicas de axé. Dessa relação com as divindades femininas advém a coragem de seguir com sua fé, a perseverança de manter suas comunidades religiosas unidas por meio de seus instintos maternais de filiação e sustentação, diante de uma sociedade opressora, colonialista e culturalmente patriarcal. O que é reforçado pelo aspecto da matrifocalidade da prática cotidiana dos terreiros. Na defesa de sua cultura, com base nas tradições africanas, o candomblé surgiu como um polo de resistência e assim se mantém em relação à população negra e periférica. As mulheres do candomblé pretas, brancas ou miscigenadas são reconhecidas por suas comunidades como referências religiosas e, por vezes, até políticas. O mito das Iyá Mi está intimamente conectado a essa condição, ressaltando o olhar sagrado do poder feminino relacionado à condição de ser mulher.

\section{AGRADECIMENTOS}

Agradecemos a toda comunidade de terreiro das religiões de matrizes africanas que contribuíram para a formação do nosso conhecimento a respeito dos assuntos tratados nesse artigo. Aos revisores da revista Ethnoscientia pelas importantes contribuições sugeridas para o aprimoramento do texto final. 
BARROS, A. A. M.; AZEVEDO, V. A. M. Iyá Mi Oxorongá: olhares sagrados do feminino no candombé. Ethnoscientia v.6 n. 2, especial, 2021. DOI: 10.22276/ethnoscientia.v6i2.396

\section{REFERÊNCIAS BIBLIOGRÁFICAS}

AMADO, J. Bahia de Todos os Santos: guia de ruas e mistérios. 1. ed. São Paulo: Companhia das Letras, 2012. 429 p.

ARAÚJO, L. A. As marcas da diáspora negra na oralidade do candomblé baiano. Revista de Estudos Linguísticos, Literários, Culturais e da Contemporaneidade, Garanhuns, n. $18 b-03$, p. 259-264, 2016.

BARROS, J. F. P. A floresta sagrada de Ossaim: os segredos das folhas. 1. ed. Rio de Janeiro: Pallas, 2011. 228 p.

BARROS, J. F. P.; NAPOLEÃO, E. Ewé Orisá: uso litúrgico e terapêutico dos vegetais nas casas de candomblés Jêje-Nagô. 7. ed. Rio de Janeiro: Bertran Brasil, 1999. 516 p.

BENISTE, J. Òrun - Àiyé: o encontro de dois mundos. Sistema de relacionamento nagôyorubá entre o céu e a terra. 12. ed. Rio de Janeiro: Bertrand Brasil, 2015. 335 p.

BENISTE, J. Mitos yorubás: o outro lado do conhecimento. 8. ed. Rio de Janeiro: Bertrand Brasil, 2016. 303 p.

BERNARDO, T. O candomblé e o poder feminino. Revista de Estudos da Religião, São Paulo, v. 5, n. 2, p. 1-21, 2005.

BERTH, J. Empoderamento. 1. ed. São Paulo: Pólen, 2019. 184 p.

BERTH, J.; SANTOS, N. P.; MENEZES, N.; CAMPANARO, P. K. Empoderamento e feminismo negro: decolonizando epistemologias e mentalidades. Mandrágora, São Paulo, v. 26, n. 1, p. $225-232,2020$.

BIRMAN, P. Fazer estilo criando gêneros: possessão e diferença de gênero em terreiros de umbanda e candomblé no Rio de Janeiro. 1. ed. Rio de Janeiro: Relume Dumará; EdUERJ, 1995. 204 p.

BONINE, E. Iaôs e equedes: quem são essas mulheres? Uma análise do papel da mulher no candomblé dito tradicional da cidade de São Paulo. Identidade!, São Leopoldo, v. 25, n. 1, p. 118-126, 2020.

CARNEIRO, S.; CURY, C. O poder feminino no culto aos Orixás. In: NASCIMENTO, E. L. (Org.). Guerreiras da natureza: mulher negra, religiosidade e ambiente. São Paulo: Selo Negro, 2008. p. 117-144.

COSSARD, G. O. Awô: o mistério dos Orixás. 2. ed. Rio de Janeiro: Pallas, 2006. 229 p.

D’OBALUAYÊ, B. Iyá-Mi Oshorongá: poderosa deusa africana. 1. ed. Rio de Janeiro: Império da Cultura, 2013. 139 p.

DUARTE, Z. A tradição oral na África. Revista do Programa de Pós-Graduação em Sociologia da UFPE, Recife, v. 15, n. 2, p. 181-189, 2009. 
ELIADE, M. Imagens e símbolos: ensaios sobre o simbolismo mágico-religioso. 1. ed. São Paulo: Martins Fontes, 1991. 178 p.

FARIA, S. C. Damas mercadoras. As pretas minas no Rio de Janeiro (século XVIII a 1850). In: SOARES, M. C. (Org.). Rotas atlânticas da diáspora africana: da Baía do Benim ao Rio de Janeiro. 2. ed. Niterói: EDUFF, 2011. p. 101-135.

JAGUN, M. Ewé: a chave do portal. 1. ed. Rio de Janeiro: Litteria, 2019. 720 p.

JOAQUIM, M. S. O papel da liderança religiosa feminina na construção da identidade negra. 1. ed. São Paulo: EDUC, FAPESP, 2001. 187 p.

KILEUY, O.; OXAGUIÃ, V. O candomblé bem explicado: nações bantu, iorubá e fon. 1 . ed. Rio de Janeiro: Pallas, 2009. 367 p.

LANDES, R. A cidade das mulheres. 1. ed. Rio de Janeiro: Civilização Brasileira, 1967. $316 \mathrm{p}$.

LORENZI, H.; SOUZA, H. M.; TORRES, M. A. V.; BACHER, L. B. Árvores exóticas no Brasil: madeireiras, ornamentais e aromáticas. 1. ed. Nova Odessa: Plantarum de Estudos, 2003. 368 p.

MAKINDE, T. Motherhood as a source of empowerment of women in yoruba culture. Nordic Journal of African Studies, Uppsala, v. 13, n. 2, p. 164-174, 2004.

MARIOSA, G. S.; MAYORGA, C. Mulheres de tabuleiro/mulheres de terreiro: trajetórias de mulheres negras. Revista Escrita da História, Marília, v. 5, n. 9, p. 98-118, 2018.

MARTINS, A. A. As mil verdades de Ifá. 1. ed. Rio de Janeiro: Pallas, 2012. 218 p.

MATORY, J. L. Feminismo, nacionalismo e a luta pelo significado do adé no candomblé: ou, como Edison Carneiro e Ruth Landes inverteram o curso da história. Revista de Antropologia, São Paulo, v. 51, n. 1, p. 107-121, 2008.

MORIM, J. Terreiro Casa Branca. Ilê Axé Iyá Nassô Oká, 2014. Disponível em: $<$ https://pesquisaescolar.fundaj.gov.br/pt-br/artigo/terreiro-casa-branca-ile-axe-iya-nassooka/>. Acesso em: 9 nov. 2020.

NOGUEIRA, R. Mulheres deusas: como as divindades e os mitos femininos formaram a mulher atual. 1. ed. Rio de Janeiro: Harper Collins, 2018. 159 p.

NOVAES, P. Herdeiras do ganho: mulheres negras, suas memórias transatlânticas e o mercado informal. In: NOVAES, P. (Org.). Ajeum: o sabor das deusas. São Paulo: Ciclo Contínuo Editorial, 2017. cap. 3, p. 21-31.

OXALÁ, A. Igbadu: a cabaça da existência. Mitos nagôs revelados. 2. ed. Rio de Janeiro: Pallas, 2014. 187 p.

PINHEIRO, E. N. O espetáculo das águas: um estudo sobre o ritual das águas de Oxalá do Axé Opô Afonjá - século XIX. 2008. 134 f. Dissertação (Mestrado em História) - 
Faculdade de Formação de Professores, Universidade do Estado do Rio de Janeiro, São Gonçalo, 2008.

PORTILHO, E. Matriarcado afreekana: narrativas cruzadas do ventre negro ao Brasil. 2019. 154 f. Dissertação (Mestrado em Relações Étnico-Raciais) - Programa de PósGraduação em Relações Étnico Raciais, do Centro Federal de Educação Tecnológica Celso Suckow da Fonseca, Rio de Janeiro, 2019.

PRANDI, R. Mitologia dos Orixás. 1. ed. São Paulo: Companhia das Letras, 2001. 591 p.

RIBEIRO, R. I. Alma africana no Brasil: os iorubás. 1. ed. São Paulo: Oduduwa. 1996a. $148 \mathrm{p}$.

RIBEIRO, R. I. Mãe-negra: o significado iorubá da maternidade. 1996b. 222 f. Tese (Doutorado em Ciência Social - Antropologia da África Negra) - Faculdade de Filosofia, Letras e Ciências Humanas, Universidade de São Paulo, São Paulo, 1996b.

SANTOS, I. M. F. Iá Mi Oxorongá: as mães ancestrais e o poder feminino na religião africana. Sankofa. Revista de História da África e de Estudos da Diáspora Africana, São Paulo, v. 1, n. 2, p. 59-80, 2008.

SANTOS, J. E. Os nàgô e a morte: Pàde, àsèsè e o culto égun na Bahia. 14 ed. Petrópolis: Vozes, 2012. $280 \mathrm{p}$.

SANTOS, J. S. M. "Mulheres de santo": gênero e liderança feminina no candomblé. Revista NGANHU, Rio de Janeiro, v. 1, n. 1, p. 47-58., 2018.

SERRANO, C.; WALDMAN, M. Memória d'África: a temática africana na sala de aula. 1. ed. São Paulo: Cortez, 2007. 328 p.

SILVA, L. A. Mulheres quebradeiras de coco babaçu e movimentos sociais. Revista P2P \& Inovação, Rio de Janeiro, v. 3, n. 2, p. 161-176, 2017.

SILVA, M. V. Gênero e religião: o exercício do poder feminino na tradição étnico-religiosa ioruba no Brasil. Revista de Psicologia da UNESP, Assis, v. 9, n. 2, p. 128-137, 2010.

SILVA, V. G. Neopentecostalismo e religiões afro-brasileiras: significados do ataque aos símbolos da herança religiosa africana no Brasil contemporâneo. Revista Mana, Rio de Janeiro v. 13, n. 1, p. 207-236, 2007.

SIQUEIRA, M. L. Iyami, Iya Agbas: dinâmica da espiritualidade feminina em templos afro-baianos. Revista de Estudos Feministas, Florianópolis, v. 3, n. 22, p. 436-446, 1995.

SIQUEIRA, M. L. Agô agô lonan: mitos, ritos e organização em terreiros de candomblé da Bahia. 1. ed. Rio de Janeiro: Mazza, 1998. 471 p.

SIQUEIRA, M. L. Iyami, Iya Agbas: dinâmica da espiritualidade feminina em templos afro-baianos. Revista de Estudos Feministas, Florianópolis, v. 3, n. 22, p. 436-446, 1996. 
SOARES, C. E. L. Comércio, nação e gênero: as negras minas quitandeiras no Rio de Janeiro 1835-1900. Revista Mestrado de História, Vassouras, v. 4, n. 1, p. 55-78, 2002.

SOUZA, D. B.; SOUZA, A. J. Itan: entre o mito e a lenda. Letras Escreve, Macapá, v. 8, n. 3, p. 99-113, 2019.

TORRES, D. A. Mulher nagô: liderança e parentesco no universo afro-brasileiro. 1. ed. Curitiba: Appris, 2015. 117 p.

VERGER, P. Grandeza e decadência do culto de Iyami Osorongá (Minha Mãe Feiticeira) entre os yorubá. In: MOURA, C. E. M. (Org.). As Senhoras do pássaro da noite. São Paulo: EDUSP, 1994. p. 13-72.

VERGER, P. Orixás: deuses iorubás na África e no novo mundo. 5. ed. Salvador: Corrupio, 2018. 308 p. 